\title{
PENGARUH STRUKTUR MODAL, UKURAN PERUSAHAAN, DAN PROFITABILITAS TERHADAP NILAI PERUSAHAAN PROPERTY DI BURSA EFEK
}

\author{
I Dewa Ayu Indah Pratiwi ${ }^{1}$ \\ I Gusti Bagus Wiksuana ${ }^{2}$ \\ Fakultas Ekonomi dan Bisnis Universitas Udayana (Unud), Bali, Indonesia \\ email: indahpratiwi2424@gmail.com
}

\begin{abstract}
ABSTRAK
Penelitian ini memiliki tujuan guna mengetahui pengaruh Struktur moddal, ukuran perusahaan, dan profitabilitas kepada Nilai perusahaan di perusahaan property \& real estate di Bursa Efek Indonesia. Populasi yang diambil untuk penelitian ini yaitu perusahaan Sub sektor Properti \& real estate. Penelitian ini memakai sampling jenuh dengan jumlah sampel sebanyak 40 perusahaan. Regresi linear berganda merupakan metode yang dipakai untuk melakukan analisis data dalam penelitian ini. Hasil penelitian menyatakan bahwa Struktur moddal mempengaruhi secara secara positif kepada Nilai Perusahaan. Hal ini dapat ditinjau dari nilai signifikansi sebesar 0,019 < 0,05 dengan nilai koefisien beta 0,077 bernilai positif. Ukuran Perusahaan mempengaruhi secara positif kepada Nilai Perusahaan. Hal ini dapat ditinjau dari nilai signifikansi sebesar $0,000<0,05$ dengan nilai koefisien beta 0,300 bernilai positif. Profitabilitas mempengaruhi secara positif kepada Nilai Perusahaan. nilai signifikansi sebesar $0,024<0,05$ dengan nilai koefisien beta 0,139 bernilai positif. Dengan kata lain semakin meningkat Profitabilitas akan semakin meningkatkan Nilai Perusahaan, sebaliknya jika Profitabilitas mengalami penurunan maka Nilai perusahaan akan mengikuti penutunan tersebut. Kata kunci: Struktur moddal, ukuran perusahaan,profitabilitas,dan nilai perusahaan
\end{abstract}

\begin{abstract}
This study aims to determine the effect of capital structure, company size, and profitability on firm value in property \& real estete companies on the Indonesia Stock Exchange. The population used in this study is the company property \& real estete sub-sector. This research uses saturated sampling with a sample of 40 companies. Multiple linear regression is a method used to analyze the data in this study. The results showed that the Capital Structure has a positive effect on Company Value. This can be seen from the significance value of $0.019<0.05$ with a positive beta coefficient of 0.077. Company size has a positive effect on firm value. This can be seen from the significance value of $0,000<0.05$ with a beta coefficient value of 0.300 positive. Profitability has a positive effect on Company Value. significance value of 0.024 $<0.05$ with a beta coefficient of 0.139 is positive. In other words, increasing profitability will further increase the value of the company, conversely if profitability decreases, the value of the company will decrease further.

Keywords: capital structure, company size, profitability, and company value
\end{abstract}




\section{PENDAHULUAN}

Manajemen keuangan memiliki tujuan memaksimumkan nilai dari perusahaan atau kemakmuran pemegang saham perusahaan. Perusahaan mengetahui bahwa kinerja keuangan digunakan sevagau salah satu aspek yang digunakan pasar untuk menilai suatu perusahaan. Perusahaan seyogyanya mempunyai tujuan dengan target berjangka panjang atau jangka pendek, tujuan utama target dengan jangka waktu yang panjang yaitu guna memaksimalkan nilai perusahaan dan memberi insentif atau bonus untuk para pemilik saham. Sedangkan adapun tujuan dari target perusahaan jangka pendek yaitu untuk mengoptimalkan secara maksimal laba yang didapat dari pemanfaatan sumber daya yang efisien (Mohammed \& Sawandi, 2003). Pada saat pendirian perusahaan, perusahaan mengadakan perluasan usaha, permodalan dibutuhkan oleh perusahaan (Hilmi, 2010). Perusahaan go public atau perusahaan yang sudah menjual sahamnya kepada khalayak umum atau public maka nilai perusahaan bisa dipahami sebagai sebagai persepsi dari pihak investor kepada perusahaan tersebut. Nilai perusahaan bisa digunakan investor sebagai acuan atau dasar untuk memantau bagaimana track record atau kinerja perusahaan pada masa depan, selain itu juga nilai perusajaan kerap dihubungkan bersama dengan harga saham perusahaan tinggi. Perusahaan ang mempunyai nilai relatif tinggimemberi petunjuk jika tingkat dari kemakmuran perusahaan yang relative tinggi pula akan membuat rasa percaya diri yang bagus dari para pemilik saham perusahaan tersebut (Wijaya \& Sedana, 2015). Selain itu perusahaan ang mempunyai nilai relatif tinggijuga akan menimbulkan rasa percaya dari seorang investor meningkat, baik itu mengenai kinerja perusahaan di masa sekarang atau prospek yang ditargetkan perusahaan untuk masa depan.

Pertumbuhan bisnis properti yang kian tahun semakin meningkat pesat serta menjanjikannnya tentu sangat dilirik bagi para investor. Namun permintaan kepada kebutuhan properti tidak sebanding dengan ketersediaan kepada produk propeti. Adanya ketimpangan antara property yang tersedia dengan permintaakn membuktikan bahwa prospek bisnis property yang memiliki potensi relative tinggi. Pada situasi seperti ini menjadikan ketertarikan bukan hanya dimata pelaku bisnis properti namun juga di mata konsumen. Kini konsumen sering membeli properti tidak untuk memenuhi keperluan atau kebutuhan hidupnya akan tetapi juga untuk melakukan investasi jangka panjang. Bisnis property adalah sektor dengan ciri khas yang sangat susah untuk diprediksi. Karena ketika ekonomi tumbuh pada angka yang relative tinggi, industry property akan booming dan bahkan mengalami keadaan yang cenderung over supplied. Akan tetapi sebaliknya terjadi jika pertumbuhan ekonomi lesu atau menurun, secara relative singkat bisnis property ini juga akan menurun dengan lumayan drastis, dan bisnis property berisiko cukup tinggi karena sumber utama dari dana sektor ini umumnya didapat dari sumber dana eksternal yaitu kredit perbankan, di lain sisi sektor bisnis ini menjalankan operasinya dengan memakai aktiva tetap yaitu berupa tanah termasuk juga bangunan di atasnya. Meskipun tanah dan bangunannya bisa juga dipakai untuk membayar hutang, namun tanah dan bangunan cenderung kurang likuid karena aktiva yang disebutkan dalam beberapa hal mengalami kesulitan untuk dihibahkan ke dalam bentuk kas dengan rentang waktu yang relative singkat 
sehingga banyak developer tidak dapat melunasi hutangnya pada waktu yang sudah mendapatkan persetujuan bersama dalam bentuk perjanjian.

Investorb bisa memakai nilai perusahaan tersebut untuk pertimbangan menilai kinerja perusahaan pada masa berikutnya yang akan datang. Nilai perusahaan mempunyai hubungan yang cukup erat dengan harga saham (Wijaya \& Sedana, 2015). Pengukuran nilai perusahaan bisa dilakukan dengan rasio price book value (PBV) merupakan perbandingan harga saham yang mempunyai nilai buku perlembar harga saham. Priice to book vallue (PBV) melakukan pengukuran pada nilai yang disajikan oleh pasar yang terletak pada manajemen juga organisasi perubahan sebagai perusahaan yang selalu tumbuh dan berekspansi (Brigham \& Houston, 2011). Peningkatan priice to book vallue (PBV) menunjukan peningkatan kemakmuran para pemegang saham yang merupakan tujuan utama dari perusahaan go public nilai priice to book vallue (PBV) dapat membantu investor untuk memperkirakan saham perusahaan tersebut dalam kondisi under value atau over value sehingga investor dapat mengambil keputusan yang tepat.

Berikut ini dapat dilihat data nilai perusahaan yang bergerak di perusahaan real estete di Bursa Efect Indonesia:

Tabel 1.

Data pergerakan Nilai Perusahaan di sektor real estete yang tercatat di Bursa Efect Indonesia Selama Tahun 2016-2018.

\begin{tabular}{|c|c|c|c|c|c|}
\hline \multirow[t]{2}{*}{ No } & \multirow[t]{2}{*}{ Nama Perusahaan } & \multirow[t]{2}{*}{ Kode } & \multicolumn{3}{|c|}{$\begin{array}{c}\text { PBV (Price To Book } \\
\text { Value) } \\
\end{array}$} \\
\hline & & & 2016 & 2017 & 2018 \\
\hline 1 & Adhi Karya Tbk & ADHI & 1.43 & 1.14 & 0.92 \\
\hline 2 & Agung Podomoro Land Tbk & APLN & 0.45 & 0.40 & 0.25 \\
\hline 3 & Alam Sutera Realty Tbk & ASRI & 0.94 & 0.82 & 0.67 \\
\hline 4 & Bekasi Asri Pemula Tbk & BAPA & 1.62 & 1.81 & 1.93 \\
\hline 5 & Bumi Citra Permai Tbk & BCIP & 214 & 252 & 287 \\
\hline 6 & Bekasi Fajar Industrial Estate Tbk & BEST & 0.65 & 0.63 & 0.48 \\
\hline 7 & Bhuwanatala Indah Permai Tbk & BIPP & 0.36 & 0.31 & 0.38 \\
\hline 8 & Sentul City Tbk & BKSL & 0.93 & 0.72 & 0.57 \\
\hline 9 & Bukit Darmo Property Tbk & BKDP & 0.93 & 1.06 & 0.88 \\
\hline 10 & Bintang Mitra Semestaraya Tbk & BMSR & 0.00 & 1.13 & 1.33 \\
\hline 11 & Bumi Serpong Damai Tbk & BSDE & 1.44 & 1.12 & 0.81 \\
\hline 12 & Cowell Development Tbk & COWL & 0.00 & 3.80 & 2.22 \\
\hline 13 & Ciputra Development Tbk & CTRA & 1.52 & 1.47 & 1.17 \\
\hline 14 & Duta Anggada Realty Tbk & DART & 0.33 & 0.27 & 0.21 \\
\hline 15 & Intiland Development Tbk & DILD & 0.00 & 0.57 & 0.49 \\
\hline 16 & Duta Pertiwi Tbk & DUTI & 1.48 & 1.20 & 0.89 \\
\hline 17 & Megapolitan Developments Tbk & EMDE & 0.00 & 1.11 & 1.06 \\
\hline 18 & Fortune Mate Indonesia Tbk & FMII & 0,00 & 2,39 & 2,94 \\
\hline 19 & Gading Development Tbk & GAMA & 455.91 & 0.46 & 0.50 \\
\hline
\end{tabular}


Lanjutan Tabel 1.

\begin{tabular}{lllccc}
\hline \multirow{2}{*}{ No } & Nama Perusahaan & Kode & \multicolumn{3}{c}{ PBV (Price To Book } \\
& & & $\mathbf{2 0 1 6}$ & $\mathbf{2 0 1 7}$ & $\mathbf{2 0 1 8}$ \\
\hline 20 & Gowa Makasar Toursm Develompment Tbk & GMTD & 1.55 & 1.47 & 1.99 \\
21 & Perdana Gapura Prima Tbk & GPRA & 0.80 & 0.43 & 0.44 \\
22 & Jaya Real Property Tbk & JRPT & 2.33 & 2.03 & 1.49 \\
23 & Kawasan Industri Jababeka Tbk & KIJA & 0.90 & 0.98 & 0.92 \\
24 & Mnc Land Tbk & KPIG & 0.01 & 0.01 & 0.01 \\
25 & Lippo Cikarang Tbk & LPCK & 0.52 & 0.28 & 0.15 \\
26 & Lippo Karawaci Tbk & LPKR & 0.76 & 0.43 & 0.22 \\
27 & Modernland Realty Ltd Tbk & MDLN & 0.66 & 0.52 & 0.41 \\
28 & Metropolitan Kentjana Tbk & MKPI & 183.87 & 292.70 & 233.96 \\
29 & Metropolitan Land Tbk & MTLA & 0.80 & 1.02 & 1.00 \\
30 & Indonesia Prima Property Tbk & OMRE & 0.10 & 0.38 & 0.81 \\
31 & Pembangunan Jaya Ancol Tbk & PJAA & 0.89 & 0.56 & 0.46 \\
32 & Pudjiadi Prestige Tbk & PUDP & 7.97 & 1.11 & 4.54 \\
33 & Pakuwon Jati Tbk & PWON & 2.75 & 2.58 & 1.95 \\
34 & Ristia Bintang Mahkotasejati Tbk & RBMS & 0.16 & 0.34 & 0.40 \\
35 & Danayasa Arthatama Tbk & SCBD & 3.35 & 3.20 & 3.47 \\
36 & Seryamas Dutamakmur Tbk & SMDM & 0.21 & 0.20 & 0.24 \\
37 & Summarecon Agung Tbk & SMRA & 0.19 & 0.12 & 1.37 \\
38 & Surya Semesta Internusa Tbk & SSIA & 1.37 & 1.00 & 1.01 \\
39 & Wijaya Karya Tbk & WIKA & 3.71 & 0.95 & 0.96 \\
40 & Waskita Karya & WSKT & 2.14 & 1.32 & 0.84 \\
\hline Sumber: www.idx.co.id, 2019 & & & &
\end{tabular}

Berdasarkan Tabel 1, dapat dinyatakan jika sektor properti dan real estete pergerakan dari tahun 2016 sampai 2018 mengalami penurunan. Penelitian ini menggunakan sektor real estete karena pergerakan harga saham sektor ini memiliki nilai yang paling rendah jika dibandingkan dengan sektor yang lainnya, sedangkan jika dilihat dari segi harga, harga property yang semakin hari mengalami peningkatan yang cukup cepat menjadi hal yang menjadi keunikan dan layak untuk diteliti karena perkembangan yang terjadi pada bidang real estete adalah salah satu dari indicator yang berkaitan dengan tumbuhnya ekonomi sebuah Negara. Harga property yang mengalami kenaikan tiap tahun akan menambah peluang bagi keuntungan yang didapat investor yang melakukan investasi dana dalam bentuk bisnis property. Namun kenyataan yang terjadi harga saham pada perusahaan yang bergerak pada sektor riil estate cenderung berfluktuaktif (tidak stabil).

Nilai perusahaan dipengaruhi oleh bermacam-macam faktor baik dari luar perusahaan maupun dari dalam perusahaan. Menurut Meiriska Febrianti factorfaktor yang mempengaruhi nilai perusahaan adalah struktur asset, profitabilitas, 
likuiditas, pertumbuhan perusahaan, ukuran perusahaan, DER (Debt to Equity Ratio). Menurut Endang Mahpudin menyebutkan bahwa faktor-faktor yang mempengaruhi nilai perusahaan adalah kebijakan deviden dan profitabilitas mempunyai pengaruh yang signifikan terhadap nilai perusahaan. Berdasarkan beberapa variabel yang mempengaruhi nilai perusahaan pada penelitian ini, menggunakan tiga variabel yang dapat mempengaruhi nilai perusahaan. Ketiga variabel tersebut yaitu struktur modal, ukuran perusahaan, dan profitabilitas. Alasan menggunakan variabel struktur modal, ukuran perusahaan dan profitabilitas dikarenakan terdapat penelitian terdahulu yang masih ada perbedaan hasil atau research gap yang meneliti ketiga variabel tersebut.

Teori struktur modal apabila posisi struktur modal berada di atas target struktur modal optimalnya maka setiap pertambahan hutang akan menurunkan nilai perusahaan. (Mohammed \& Sawandi, 2003) menyatakan bahwa struktur modal sangat penting pada bagaimana perusahaan membiayai keseluruhan operasi dan pertumbuhannya dengan menggunakan berbagai sumber dana. Selain itu, Cuong (2012), menyatakan bahwa teori trade-off memprediksi bahwa perusahaan yang aman, perusahaan dengan aset yang lebih berwujud dan lebih banyak penghasilan kena pajak untuk melindungi harus memiliki rasio utang yang tinggi, perusahaan dengan ukuran lebih besar dan lebih banyak likuiditas harus memiliki rasio utang yang tinggi. Lebih lanjut, (Mohamad \& Abdullah, 2012) menyatakan bahwa teori Trade off menyiratkan bahwa leverage memiliki hubungan positif dengan profitabilitas yang bertentangan dengan teori pecking order. Teori tradeoff memprediksi hubungan positif anatara struktur modal dengan nilai perusahaan dengan asumsi keuntungan pajak masih lebih besar dari biaya tekanan finansial dan biaya keagenan. Maka dari itu dapat diketahui bahwa penggunaan hutang akan meningkatkan nilai perushaan tetapi hanya sampai pada titik tertentu setelah titik tersebut, penggunaan hutang justru menurunkan nilai perusahaan. Indikator struktur modal yang digunakan dalam penelitian ini adalah debt to equity ratio (DER). Debt to equity ratio (DER) merupakan rasio untuk mengukur seberapa jauh perusahaan dibelanjai dari pihak debitur makin tinggi rasio ini berarti makin besar dana yang diambil dari luar.

Ukuran perusahaan adalah jumlah dan variasi kapasitas produksi dan kemampuan yang dimiliki perusahaan atau jumlah dan variasi layanan yang dapat diberikan perusahaan secara bersamaan kepada pelanggannya. Ukuran perusahaan adalah faktor utama dalam menentukan profitabilitas dan nilai pasar perusahaan karena skala ekonomi yang dapat ditemukan dalam pandangan neo-klasik tradisional perusahaan (Hafzan, 2017). Ini mengungkapkan bahwa, berbeda dengan perusahaan kecil, barang dapat diproduksi dengan biaya yang jauh lebih rendah oleh perusahaan besar. Sesuai dengan konsep ini, hubungan positif antara ukuran perusahaan dan profitabilitas dan nilai pasar diharapkan (Zeyn, 2012). Bertentangan dengan ini, teori-teori alternatif dari perusahaan menyarankan bahwa perusahaan-perusahaan besar berada di bawah kendali manajer yang mengejar tujuan yang mementingkan diri sendiri dan oleh karena itu fungsi maksimalisasi utilitas manajerial dapat menggantikan maksimalisasi keuntungan dari fungsi tujuan perusahaan. Dalam menentukan keberhasilan bisnis suatu perusahaan, profitabilitas dan nilai pasar melakukan peran yang dinamis. 
Pembelanjaan yang dirancang oleh manajer keuangan dapat membentuk sebuah struktur moneter yang bisa memberikan gambaran komposisi dari perbandingan sumber keuangan perusahaan untuk melakukan pembiayaan operasional pada perusahaan. Sumber dana perusahaan digambarkan dari modal asing dan modal yang dimiliki oleh perusahaan tersebut yang berpatokan pada debt to equity ratio (DER) (Wiagustini, 2010). Struktur moddal mempengaruhi secara yang positif pada nilai dari sebuah perusahaan (Rizqia, et al. 2013). Hasil penelitian lain yang dilaksanakan oleh (Eka Lestari, 2010)menunjukkan halwa secara parsial Struktur moddal mempengaruhi secara yang cukup signifikan dan positif pada nilai perusahan.

Hasil penelitian sebelumnya (Chen \& Chen, 2011) memperoleh hasil Struktur moddal mempengaruhi secara secara positif dan signifikan kepada nilai perusahaan. Bahwa terdapat hubungan yang berlangsung secara positif juga signifikan yang terjadi pada nilai perusahaan, temuan ini didukung oleh trad off theory yang menyatakan bahwa (dengan asumsi titik target Struktur moddal yang dicapai belum optimal) terjadinya peningkatan pada rasio utang untuk stuktur modal akan memberi peningkatan nilai dari perusahaan.

$\mathrm{H}_{1}$ : Struktur moddal mempengaruhi secara yang positif dan signifikan kepada nilai perusahaan property dan real estete di Bursa Efect Indonesia.

(Sunarto \& Budi, 2009) memberikan hasil penelitian yang secara signifikan bahwa adanya pengaruh yang positif antara ukuran dari sebuah perusahaan kepada nilai perusahaan, yang bisa didefinisikan secara terpisah bahwa meningkatnya ukutan perusahaan akan mampu membuat perusahaan mendapat dana dengan cara yang lebih mudah, dan kemudian bisa dilakukan pemanfaatan oleh pihak manajerial guna melakukan peningkatan dari nilai perusahaan.

Ukuran perusahan adalah penggambaran mengenai ukuran perusahaan berkaitan dengan ukuran besar dan kecil perusahaan yang dapat ditinjau pada jumlah keseluruhan aktiva perusahaan yang dilaporkan pada neraca di akhir tahun anggaran. Jadi ukuran perusahan menunjukan besar kecilnya perusahaan yang bisa ditinju dari jumlah modal yang dipakai dan total seluruh aktiva yang dipunyai (Modigliani \& Miller, 2008).

Ukuran perusahaan bisa diwakili lewat jumlah keseluruhan asset atau jumlah kekayaan perusahaan yang dilaporkan pada akhir tahun. Perusahaan yang tergolong ukuran besar biasanya lebih fleksibel dan lebih menerima untuk urusan pendanaan di pasar modal (Ahmad, et al. 2012). Hal tersebut juga memiliki arti bahwa perusahaan yang besar memiliki kemudahan dalam akses untuk menuju ke pasar modal.

$\mathrm{H}_{2}$ : Ukuran Perusahaan mempengaruhi secara yang positif dan signifikan kepada nilai perusahaan property dan real estete real estete di Bursa Efect Indonesia.

Profitabilitas diasumsikan sebagai rasio mengenai laba sebuah perusahaan. Rasio nilai profitabilitas yang relatif tinggi pada perusahaan akan memberi daya tarik pada minat investor untuk melakukan penanaman modal di perusahaan tersebut(Huang, Shih, Huang, \& Liu, 2006). Keuntungan yang tinggi akan memberikan indiaksi prospek perusahaan yang baik sehingga memicu investor 
untuk menaikan permintaan saham yang akan mempengaruhi nilai perusahaan (Chen \& Chen, 2011). Hal tersebut yang menjadi dasar pengambilan keputusan investor bahwa perusahaan dengan ini yang kemampuan perolehan laba lebih tinggi lebih mampu untuk meningkatkan kemakmuran dari pemegang saham. Maka jika laba perusahaan yang dihasilkan semakin maka semakin meningkat nilai sebuah perusahaan (Chen \& Chen, 2011). Profitabilitas mempengaruhi secara yang positif kepada nilai perusahaan. Penelitian yang dihasilkan oleh (Hilmi, 2010) mendukung pernyataan tersebut dimana profitabilitas berpenganuh positif kepada nilai perusahaan.

Berdasarkan kajian teori dan empiris tersebut maka dapat ditarik hipotesis seperti yang dijabarkan berikut:

H3: Profitabilitas mempengaruhi secara yang positif kepada nilai perusahaan property dan real estete.

Nilai perusahaan merupakan harga yang bersedia dibayar oleh calon pembeli apabila perusahaan dijual. Nilai perusahaan yang tinggi sering dipandang sebagai sebuah hal yang penting bagi investor karena nilai perusahaan merupakan indikator bagi pasar dalam menilai sebuah perusahaan. Semakin tinggi nilai perusahaan, semakin besar kemakmuran yang akan diterima oleh pemilik perusahaan (Wiagustini, 2010)

Nilai perusahaan adalah nilai yang mencerminkan berapa harga yang bersedia dibayar oleh investor untuk suatu perusahaan. Harga saham yang tinggi membuat nilai perusahaan juga tinggi. Memaksimalkan nilai perusahaan sangat penting artinya bagi suatu perusahaan, karena dengan memaksimalkan nilai perusahaan berarti juga memaksimalkan kemakmuran pemegang saham yang merupakan tujuan utama perusahaan (Wulandari, et al, 2015)

Menurut (Pramana \& Mustanda, 2016) nilai perusahaan sangat penting karena dengan nilai perusahaan yang tinggi akan dikuti oleh tingginya kemakmuran pemegang saham. Semakin tinggi harga saham semakin tinggi pula nilai perusahaan. Nilai perusahaan yang tinggi menjadi keinginan para pemilik perusahaan, sebab dengan nilai yang tinggi menunjukkan kemakmuran pemegang saham juga tinggi. Kekayaan pemegang saham dan perusahaan dipresentasikan oleh harga pasar dari saham yang merupakan cerminan dari keputusan investasi pendanaan (financing) dan manajemen aset. Adanya peluang investasi dapat memberikan sinyal positif tentang pertumbuhan perusahaan dimasa yang akan datang, sehingga dapat meningkatkan nilai perusahaan.

Struktur modal merupakan pendanaan kegiataan perusahaan dari kombinasi hutang dan modal sendiri (Brigham \& Houston, 2011) juga berpendapat bahwa struktur modal ialah kombinasi antara utang dan ekuitas yang akan digunakan dalam kegiatan operasi perusahaan. Struktur modal yang optimal bagi suatu perusahaan diartikan sebagai struktur yang akan memaksimalkan harga saham perusahaan tersebut. Jika utang sesungguhnya berada di bawah target, pinjaman perlu ditambah. Jika rasio utang melampaui target, maka saham akan dijual. Struktur modal yang optimal bagi suatu perusahaan diartikan sebagai struktur yang akan memaksimalkan harga saham perusahaan tersebut. Pendanaan perusahaan dapat dilakukan dengan memilih alternatif penggunaan utang, ataupun ekuitas. Pemilihan pendanaan dari pihak manajemen nantinya diharapkan akan 
menjadi struktur modal yang optimal. Struktur modal optimal adalah struktur modal yang menngoptimalkan keseimbangan antara risk dan return sehingga memaksimalkan harga saham. Pada umumnya nilai perusahaan akan maksimal jika biaya modal adalah minimal (Chen \& Chen, 2011). Leverage mengacu pada sejauh mana perusahaan memanfaatkan pinjaman uang mereka (pembiayaan utang) untuk meningkatkan profitabilitas dan diukur dengan total kewajiban terhadap ekuitas. Perusahaan-perusahaan yang meminjam uang dalam jumlah besar selama resesi bisnis lebih mungkin default untuk melunasi hutang mereka saat jatuh tempo; mereka akan berakhir dengan leverage yang tinggi dan lebih mungkin berakhir dengan potensi risiko kebangkrutan. Sebaliknya, semakin rendah pinjaman perusahaan, semakin rendah leverage, dan risiko kebangkrutan pada akhirnya akan lebih rendah yang menandakan bahwa bisnis akan terus beroperasi.

Teori trade-off memprediksi bahwa perusahaan yang aman, perusahaan dengan aset yang lebih berwujud dan lebih banyak penghasilan kena pajak untuk melindungi harus memiliki rasio utang yang tinggi, perusahaan dengan ukuran lebih besar dan lebih banyak likuiditas harus memiliki rasio utang yang tinggi. Sementara perusahaan berisiko, perusahaan dengan aset lebih berwujud yang nilainya akan menghilang jika terjadi likuidasi, harus lebih mengandalkan pembiayaan ekuitas (Sari, et al, 2017). Dalam hal profitabilitas, teori trade-off memperkirakan bahwa perusahaan yang lebih menguntungkan harus berarti lebih banyak kapasitas melayani utang dan lebih banyak penghasilan kena pajak untuk melindungi; karena itu rasio utang yang lebih tinggi akan diantisipasi. Menurut teori trade-off, perusahaan dengan peluang pertumbuhan tinggi harus pinjam lebih sedikit karena lebih mungkin kehilangan nilai dalam kesulitan keuangan. Lebih lanjut, (Mohamad \& Abdullah, 2012), menyatakan bahwa teori Trade off menyiratkan bahwa leverage memiliki hubungan positif dengan profitabilitas yang bertentangan dengan teori pecking order.

Teori trade off mempertimbangkan biaya kebangkrutan yang terkait dengan pembiayaan utang dan manfaat dari keuntungan pajak. Teori trade-off menyatakan bahwa suatu perusahaan dapat menetapkan target hutang ke nilai perusahaan, dan secara bertahap bergerak ke arah itu. Menurut teori ini, peningkatan tingkat utang akan meningkatkan biaya kebangkrutan, kesulitan keuangan dan agensi, sehingga mengurangi nilai perusahaan. Dengan demikian, perusahaan perlu menemukan keseimbangan di mana tingkat utang akan dapat mengimbangi biaya (seperti keuntungan pajak dari utang) dengan biaya dari kesulitan keuangan yang mungkin terjadi. Menurut teori ini, perusahaan dengan pertumbuhan tinggi memiliki lebih banyak risiko dan biaya kesulitan keuangan yang lebih tinggi, sehingga pertumbuhan memiliki hubungan terbalik dengan tingkat utang. Namun, jika perusahaan memiliki tingkat aset tetap yang lebih tinggi untuk dijadikan jaminan untuk pembiayaan utang, itu akan memberikan akses yang lebih mudah bagi perusahaan untuk mendapatkan utang, sehingga memberikan hubungan positif antara tangibilitas aset dan tingkat utang.

Menurut Capon et al. (2011), ukuran perusahaan memiliki peran penting dalam kinerja perusahaan karena berbagai alasan. Dalam perspektif studi tertentu, ukuran dapat menjadi proksi dari sumber daya perusahaan. Karena perusahaan 
yang lebih besar memiliki lebih banyak sumber daya organisasi, mereka memberi perusahaan yang lebih besar peralatan yang lebih baik untuk mencapai tujuan mereka (Capon et al., 2011). Ukuran juga dapat mewakili kemungkinan default dan volatilitas aset perusahaan. Ini mengasumsikan bahwa perusahaan besar sulit untuk dilikuidasi. Majdumdar dan Chhibber (1997) juga menunjukkan bahwa perusahaan yang lebih besar menghasilkan kinerja yang superior dibandingkan perusahaan yang lebih kecil. Argumen teoretis lainnya (Onder, 2003, Tran, 2005 dan Surajit dan Saxena, 2009) menyatakan bahwa perusahaan yang lebih besar dapat merancang cara dan cara yang lebih baik untuk memerangi risiko dan ketidakpastian pasar dan memiliki peluang yang lebih baik untuk mengimbangi kerugian acak dan berkinerja lebih baik. Selain itu, ukuran membawa daya tawar terhadap pemasok dan pesaing, perusahaan besar dapat membeli situs terbaik dengan keunggulan terkait, teknologi unggul, dan pakar profesional terbaik karena kontrolnya terhadap pasar.

Kemampuan perusahan untuk menghasilkan laba biasa disebut dengan profitabilitas. Profitabilitas sangatlah penting untuk perusahaan dalam rangka mempertahankan kelangsungan usahanya dalam jangka panjang, hal dikarenakan profitabilitas menunjukkan apakah perusahaan mempunyai prospek yang bagus di masa yang akan datang atau tidak. Menurut (Febri, et al. 2019)profitabilitas merupakan faktor yang dapat mempengaruhi nilai perusahaan. Jika manajer mampu mengelola perusahaan dengan baik maka biaya yang akan menjadi lebih kecil sehingga laba yang dihasilkan menjadi lebih besar. Besar atau kecilnya laba ini yang mempengaruhi nilai perusahaan.

Profitabilitas atau laba merupakan pendapatan dikurangi beban dan kerugian selama periode pelaporan. Analisis mengenai profitabilitas sangat penting bagi kreditor dan investor ekuitas. Bagi kreditor, laba merupakan sumber pembayaran bunga dan pokok pinjaman, sedangkan bagi investor ekuitas. Bagi kreditor, laba merupakan sumber pembayaran bunga dan pokok pinjaman, sedangkan bagi investor ekuitas, laba merupakan salah satu faktor penentu perubahan nilai efek. Hal yang terpenting perusahaan adalah bagaimana laba tersebut bisa memaksimalkan pemegang saham bukan seberapa besar laba yang dihasilkan oleh perusahaan (Rizqia et al., 2013).

Menurut (Wijaya \& Sedana, 2015), profitabilitas adalah kemampuan perusahaan dalam memperoleh laba. Para investor menanamkan saham pada perusahaan adalah untuk mendapatkan return. Semakin tinggi kemampuan perusahaan memperoleh laba, maka semakin besar return yang diharapkan investor, sehingga menjadikan nilai perusahaan menjadi lebih baik.

(Wiagustini, 2010)adalah kemampuan perusahaan dalam memperoleh laba dapat juga digunakan sebagai alat untuk mengukur tingkat efektivitas dalam suatu perusahaan. Indikator ini juga dapat digunakan untuk mengukur kemampuan perusahaan untuk menghasilkan laba dan dapat membantu dalam menentukan efektivitas perusahaan dalam mengelola sumber daya yang dimilikinya. Dengan pengukuran rasio profitabilitas secara berkala, manajemen dapat menerapkan langkah-langkah perbaikan dan efesiensi secara. Rasio yang sering digunakan untuk mengukur tingkat profitabilitas adalah return on asset (ROA) return on equily (ROE) serta nel profit margin (NPM). Rasio profitabilitas atau rasio 
rentabilitas menunjukkan keberhasilan dalam menghasilkan keuntungan. Rasio profitabilitas merupakan kemampuan perusahaan untuk menghasilkan laba pada masa mendatang dan merupakan indikator dari keberhasilan operasi perusahaan.

Profitabilitas merupakan daya tarik utama pemilik (pemegang saham) karena profitabilitas adalah hasil yang diperoleh melalui usaha manajemen atas dana yang di investasikan oleh para pemegang saham dan profitabilitas juga mencerminkan pembagian laba yang menjadi haknya yaitu seberapa banyak dana yang diinvestasikan kembali dan seberapa banyak yang dibayarkan sebagai dividen tunai ataupun dividen saham kepada para pemilik saham.

Profitabilitas dapat diukur menggunakan rasio profiabilitas. Rasio yang umumnya digunakan untuk mengukur profitabilitas adalah sebagai berikut: Pertama, return on investment (ROI) menurut ROI adalah pengukuran kemampuan perusahaan secara keseluruhan didalam menghasilkan keuntungan dengan jumlah keseluruhan aktiva yang tersedia didalam perusahaan, dimana semakin tinggi rasio ini semakin baik keadaan perusahaan. Dengan menggunakan rasio ini, akan dapat diketahui apakah perusahaan efisien dalam memanfatkan aktivanya untuk membiayai kegiatan operasional perusahaan. Rasio ini juga memberikan ukuran yang lebih baik atas profitabilitas perusahaan karena menunjukkan efektifitas manajemen dalam menggunakan aktiva untuk memperoleh pendapatan.

\section{METODE PENELITIAN}

Adapun desain penelitian yang dipakai pada penelitian ini adyaitualah menggunakan metode kuantitatif berbentuk asosiatif yaitu penelitian yang menyatakan hubungan dari dua variable atau lebih. Penelitian ini memiliki tujuan guna mengetahui hubungan variabel Struktur moddal, ukuran perusahaan, dan profitabilitas kepada nilai perusahaan.

Penelitian ini dilakukan pada perusahaan perusahaan sektor property, real estete yang namanya telah terdaftar di Bursa Efect Indonesia (BEI) pada rentang tahun 2016 - 2018 dengan mengakses data melalui situs resmi BEI (www.idx.co.id).

Populasi yang dipakai pada penelitian ini yaitu perubahaan property, real estete di Bursa Efect Indonesia selama periode 2016 - 2018. Yaitu sebanyak 47 perusahaan. Sampel ditentukan dengan metode dengan metode sampling jenuh karena jumlah populasi kurang dari 100, maka semua populasi digunakan sebagai pengambilan sampel.

Tabel 2.

\begin{tabular}{lll}
\multicolumn{2}{l}{ Perusahaan Real estete Yang Menerbitkan Jumlah Sampel Penelitian } \\
\hline No & \multicolumn{1}{c}{ Kriteria } & Jumlah \\
\hline 1 & Perusahaan real estete yang terdaftar di BEI periode 2016-2018 & 47 \\
2 & $\begin{array}{l}\text { Perusahaan yang tidak menerbitkan laporan keuangan sesuai dengan } \\
\text { variable Struktur moddal, Ukuran Perusahaan, Profitabilitas, dan Nilai }\end{array}$ & $(7)$ \\
& perusahaan periode 2016-2018 & 40 \\
& Jumlah sampel penelitian & 120 \\
\hline & Total sampel amatan 40 x 3 th & \\
\hline
\end{tabular}

Sumber: $\underline{w w w . i d x . c o m, 2019}$ 
Teknik analisis data yang dipakai untuk menganalisis hasil adalah teknik Analisis regresi linier berganda akan membantu dalam mengetahui pengaruh variabel bebas yaitu Struktur moddal $\left(\mathrm{X}_{1}\right)$, Ukuran perusahaan $\left(\mathrm{X}_{2}\right)$ dan profitabilitas $\left(\mathrm{X}_{3}\right)$ kepada variabel terikat yaitu Nilai perusahaan $(\mathrm{Y})$. persamaan regresi linier berganda dapat dirumuskan sebagai berikut:

$$
\mathrm{Y}=\alpha+\beta_{1} X_{1}+\beta_{2} X_{2}+\beta_{3} X_{3}+e
$$

\section{HASIL DAN PEMBAHASAN}

Tabel 3 .

Analisis Statistik Deskriptif

\begin{tabular}{lrrrrr}
\hline \multicolumn{7}{c}{ Descriptive Statistics } & & \\
\hline & N & Minimum & Maximum & \multicolumn{1}{c}{ Mean } & Std. Deviation \\
\hline Struktur moddal & 120 & .04 & 225.15 & 2.9298 & 20.49392 \\
Ukuran Perusahaan & 120 & 25.50 & 32.45 & 29.2408 & 1.52877 \\
Profitabilitas & 120 & -.13 & 7.55 & .1457 & .68601 \\
Nilai Perusahaan & 120 & .00 & 455.91 & 10.6425 & 55.65195 \\
Valid N (listwise) & 120 & & & & \\
\hline Sumber: Data sekun & & & &
\end{tabular}

Sumber: Data sekunder diolah, 2019 (Lampiran 1)

Berdasarkan hasil analisis statistik deskriptif data yang ditunjukkan pada Tabel 3 didapat hasil bahwa sampel yang berjumlah 120 dengan penjabaran sebagai berikut, Struktur moddal memiliki nilai minimal 0,04. Nilai maksimal sebesar 225,15 dan rata - rata sebesar 2,9298 dengan standar deviasi sebesar 20,49392. Ukuran Perusahaan memiliki nilai minimal 25,50. Nilai maksimal sebesar 32,45 dan rata - rata sebesar 29,2408 dengan standar deviasi sebesar 1,52877. Profitabilitas memiliki nilai minimal -0,13. Nilai maksimal sebesar 7,55 dan rata - rata sebesar 0,1457 dengan standar deviasi sebesar 0,68601. Nilai Perusahaan memiliki nilai minimal 0,00. Nilai maksimal sebesar 455,91 dan rata rata sebesar 10,6425 dengan standar deviasi sebesar 55,65195.

Tabel 4 .

Hasil Uji Normalitas

\begin{tabular}{llr}
\hline \multicolumn{2}{c}{ One-Sample Kolmogorov-Smirnov Test } & Unstandardized Residual \\
\hline $\mathrm{N}$ & & 120 \\
Normal Parameters ${ }^{\mathrm{a}, \mathrm{b}}$ & Mean & .0000000 \\
& Std. Deviation & .60223772 \\
Most Extreme Differences & Absolute & .064 \\
& Positive & .064 \\
Test Statistic & Negative & -.061 \\
Asymp. Sig. (2-tailed) & & .064 \\
a. Test distribution is Normal. & & $.200^{\text {c,d }}$ \\
b. Calculated from data. & \\
c. Lilliefors Significance Correction. & \\
d. This is a lower bound of the true significance. & \\
\hline Sumber: Data sekunder diolah, 2019 (Lampiran 3)
\end{tabular}

Sumber: Data sekunder diolah, 2019 (Lampiran 3) 
Berdasarkan Tabel 4. dapat dilihat bahwa nilai Kolmogorov Sminarnov (KS) sebesar 0,064 dan nilai Asymp. Sig. (2-tailed) sebesar 0,200. Hasil tersebut mengindikasikan bahwa model persamaan regresi tersebut berdistribusi normal karena nilai Asymp. Sig. (2-tailed) lebih besar dari nilai alpha 0,05 (0,200 > 0,05). Selain itu, uji normalitas dapat dilihat pada grafik dibawah.

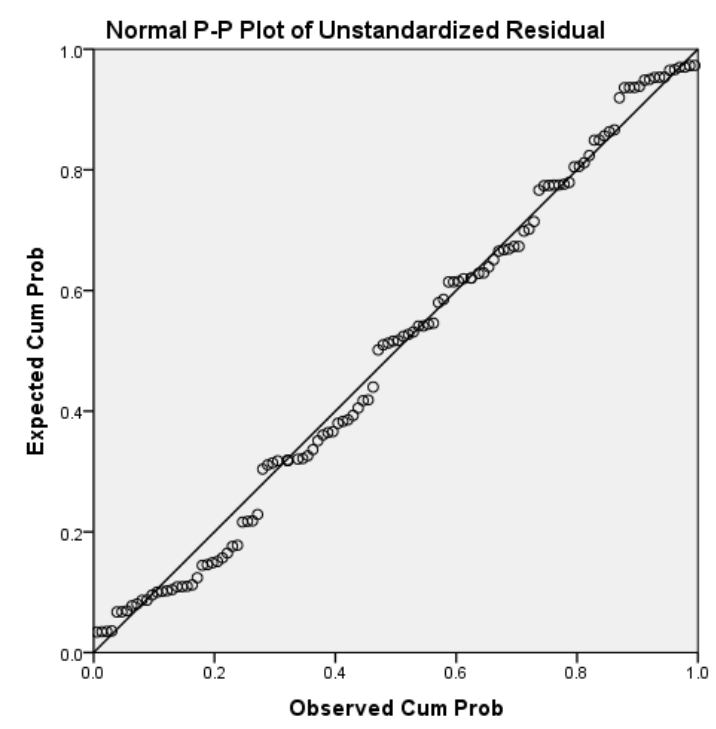

Gambar 1. P-P Plot

Sumber: Data sekunder diolah, 2019 (Lampiran 3)

Berdasarkan hasil grafik p-p plot diperoleh bahwa data menyebar disekitar garis diagonal atau grafik histogramnya menunjukan pola distribusi normal, maka model regresi memenuhi asumsi normalitas.

\section{Tabel 5 .}

Hasil Uji Multikolinieritas

\begin{tabular}{|c|c|c|c|}
\hline \multicolumn{4}{|c|}{ Coefficients $^{\mathrm{a}}$} \\
\hline \multirow[b]{2}{*}{ Model } & & \multicolumn{2}{|c|}{ Collinearity Statistics } \\
\hline & & Tolerance & VIF \\
\hline \multirow[t]{3}{*}{1} & Struktur moddal & .779 & 1.284 \\
\hline & Ukuran Perusahaan & .771 & 1.297 \\
\hline & Profitabilitas & .971 & 1.030 \\
\hline \multicolumn{4}{|c|}{ a. Dependent Variable: Nilai Perusahaan } \\
\hline
\end{tabular}

Sumber: Data sekunder diolah, 2019 (Lampiran 2)

Berdasarkan Tabel 5. dapat dilihat bahwa nilai tolerance dan VIF dari variabel Struktur moddal berturut-turut 0,779 dan 1,284, nilai tolerance dan VIF dari variabel Ukuran Perusahaan berturut-turut 0,771 dan 1,297 dan nilai tolerance dan VIF dari variabel Profitabilitas berturut-turut 0,971 dan 1,030 semua menunjukkan nilai tolerance untuk setiap variabel lebih besar dari 0,1 dan 
nilai VIF lebih kecil dari 10 yang berarti model persamaan regresi bebas dari multikolinearitas.

Tabel 6.

Hasil Uji Autokorelasi

\begin{tabular}{lcrrrr}
\hline \multicolumn{5}{c}{ Model Summary } \\
\hline Model & R & R Square & $\begin{array}{c}\text { Adjusted R } \\
\text { Square }\end{array}$ & $\begin{array}{l}\text { Std. Error of } \\
\text { the Estimate }\end{array}$ & Durbin-Watson \\
\hline 1 & $.824^{\mathrm{a}}$ & .679 & .671 & .60998 & 1.956 \\
\hline
\end{tabular}

a. Predictors: (Constant), Profitabilitas, Struktur moddal, Ukuran Perusahaan

b. Dependent Variable: Nilai Perusahaan

Sumber: Data sekunder diolah, 2019 (Lampiran 2)

Pada Tabel 6. dapat dilihat bahwa nilai nilai Durbin Watson (d-hitung) sebesar 1,956. Dengan signifikan sebesar 0,05 dan $\mathrm{N}=120$ dan jumlah variabel bebas $\mathrm{k}=3$, maka diperoleh nilai $\mathrm{du}=1,7536$ diperoleh nilai $\left(4-\mathrm{d}_{\mathrm{u}}\right)$ sebesar $4-$ $1,7536=2,2464$. Oleh karena nilai Durbin Watson (d-hitung) sebesar 1,956 berada diantara 1,7536 dan 2,2464 sehingga dapat disimpulkan bahwa tidak ada autokorelasi positif dan negatif.

Tabel 7.

Hasil Uji Heteroskedastisitas

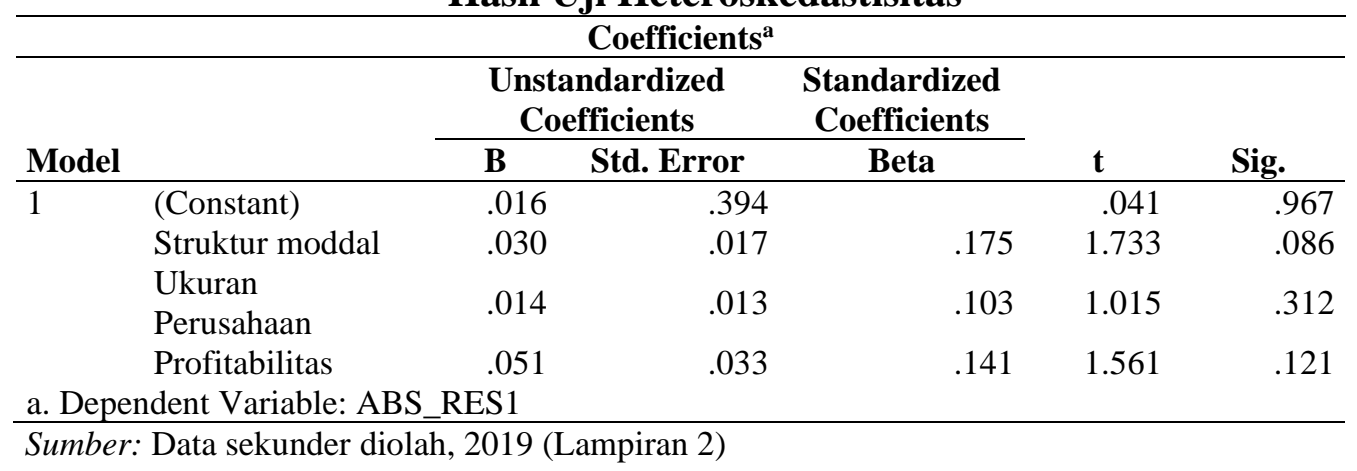

Pada Tabel 7. dapat dilihat bahwa nilai signifikansi dari variabel Struktur moddal sebesar 0,086, nilai signifikan dari variabel Ukuran Perusahaan sebesar 0,312 dan nilai signifikansi dari variabel Profitabilitas sebesar 0,121 . Nilai tersebut lebih besar dari 0,05 yang berarti tidak terdapat gejala heteroskedastisitas.

Berdasarkan output scatterplot pada Gambar 2, terlihat bahwa tidak ada pola yang jelas, serta titik-titik menyebar diatas dan dibawah angka 0 pada sumbu Y. Sehingga dapat disimpulkan bahwa tidak terjadi masalah heteroskedastisitas.

Berdasarkan hasil analisis regresi seperti yang disajikan pada Tabel 9. maka dapat dibuat persamaan struktural sebagai berikut:

$$
Y=-8,459+0,077 X_{1}+0,300 X_{2}+0,139 X_{3}
$$

Hasil persamaan tersebut menunjukkan besar dan arah pengaruh masingmasing variabel bebas pada variabel terikat. Koefisien regresi yang bertanda positif berarti mempunyai pengaruh yang searah dengan Nilai Perusahaan. Berdasarkan persamaan regresi linier berganda tersebut dapat dijelaskan 
koefisien-koefisiennya sebagai berikut: Nilai konstanta sebesar -8,459, artinya jika variabel Struktur moddal, Ukuran Perusahaan, Profitabilitas bernilai 0 maka nilai Nilai Perusahaan sebesar -8,459. Nilai koefisien variabel Struktur moddal $\left(\mathrm{X}_{1}\right)$ bernilai positif 0,077 , artinya apabila Struktur moddal $\left(\mathrm{X}_{1}\right)$ mengalami peningkatan satu satuan dengan asumsi variabel ukuran perusahaan dan Profitabilitas dianggap tetap maka nilai Nilai Perusahaan akan meningkat sebesar 0,077. Nilai koefisien variabel Ukuran Perusahaan $\left(\mathrm{X}_{2}\right)$ bernilai positif 0,300 , artinya apabila Ukuran Perusahaan $\left(\mathrm{X}_{2}\right)$ mengalami peningkatan satu satuan dengan asumsi variabel Struktur moddal dan Profitabilitas dianggap tetap maka Nilai Perusahaan akan meningkat sebesar 0,300. Nilai koefisien variabel Profitabilitas $\left(\mathrm{X}_{3}\right)$ bernilai positif 0,139 , artinya apabila Profitabilitas $\left(\mathrm{X}_{3}\right)$ mengalami peningkatan satu satuan dengan asumsi variabel Struktur moddal dan Ukuran Perusahaan dianggap tetap maka Nilai Perusahaan akan meningkat sebesar 0,139 .

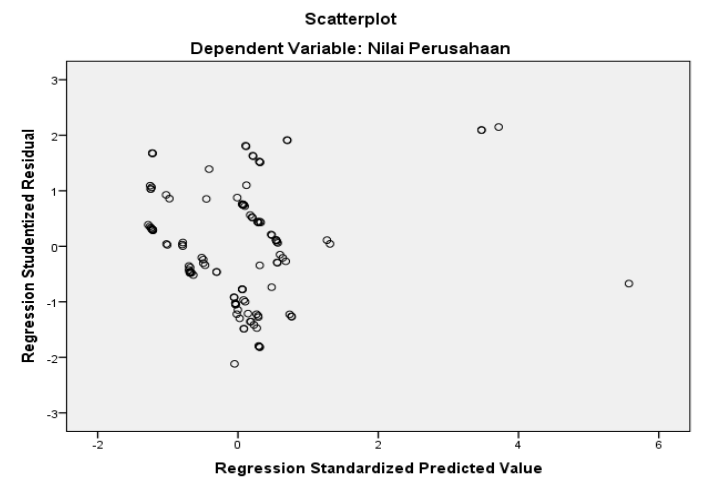

Gambar 2 Scatterplot

Sumber: Data sekunder diolah, 2019 (Lampiran 4)

Tabel 9.

Hasil Analisis Regresi Linier Berganda

\begin{tabular}{|c|c|c|c|c|c|c|}
\hline \multicolumn{7}{|c|}{ Coefficients $^{\mathrm{a}}$} \\
\hline \multirow[b]{2}{*}{ Model } & & \multicolumn{2}{|c|}{$\begin{array}{l}\text { Unstandardized } \\
\text { Coefficients }\end{array}$} & \multirow{2}{*}{$\begin{array}{c}\text { Standardized } \\
\text { Coefficients } \\
\text { Beta }\end{array}$} & \multirow[b]{2}{*}{$t$} & \multirow[b]{2}{*}{ Sig. } \\
\hline & & B & Std. Error & & & \\
\hline 1 & (Constant) & -8.459 & .729 & & -11.600 & .000 \\
\hline & $\begin{array}{l}\text { Struktur } \\
\text { moddal }\end{array}$ & .077 & .032 & .142 & 2.384 & 019. \\
\hline & $\begin{array}{l}\text { Ukuran } \\
\text { Perusahaan }\end{array}$ & .300 & .025 & .728 & 12.157 & .000 \\
\hline a. Depe & $\begin{array}{l}\text { Profitabilitas } \\
\text { dent Variable: }\end{array}$ & $\begin{array}{l}.139 \\
\text { Perusaha }\end{array}$ & .061 & .122 & 2.291 & . 024 \\
\hline
\end{tabular}

Sumber: Data sekunder diolah, 2019 (Lampiran 3) 
Berdasarkan Tabel 10. besarnya pengaruh variabel bebas kepada variabel terikat yang ditunjukkan oleh nilai determinasi total (Adjused $R$ Square) sebesar 0,671 mempunyai arti bahwa sebesar $67,1 \%$ variasi Nilai Perusahaan dipengaruhi oleh variasi Profitabilitas, Ukuran Perusahaan, dan Struktur moddal, sedangkan sisanya sebesar 32,9\% dijelaskan oleh faktor lain yang tidak dimasukkan ke dalam model

Tabel 10.

Hasil Analisis Koefisien Deteminasi

\begin{tabular}{lcccc}
\hline \multicolumn{4}{c}{ Model Summary } \\
\hline Model & R & R Square & $\begin{array}{c}\text { Adjusted R } \\
\text { Square }\end{array}$ & $\begin{array}{c}\text { Std. Error of } \\
\text { the Estimate }\end{array}$ \\
\hline 1 & $.824^{\mathrm{a}}$ & .679 & .671 & .60998 \\
\hline a. Predictors: (Constant), Profitabilitas, Struktur moddal, Ukuran \\
$\begin{array}{l}\text { Perusahaan } \\
\text { b. Dependent Variable: Nilai Perusahaan }\end{array}$ \\
Sumber: Data sekunder diolah, 2019 (Lampiran 4)
\end{tabular}

Tabel 11.

Hasil Uji Kelayakan Model

\begin{tabular}{llrrrrr}
\hline \multicolumn{7}{c}{ ANOVA $^{\mathrm{a}}$} \\
\hline \multirow{2}{*}{ Model } & & \multicolumn{4}{c}{ Mean } \\
\hline 1 & Regression & Sum of Squares & df & Square & \multicolumn{1}{c}{ F } & Sig. \\
\hline & Residual & 91.233 & 3 & 30.411 & 81.735 & $.000^{\mathrm{b}}$ \\
& Total & 43.160 & 116 & .372 & & \\
& 134.394 & 119 & & &
\end{tabular}

a. Dependent Variable: Nilai Perusahaan

b. Predictors: (Constant), Profitabilitas, Struktur moddal, Ukuran Perusahaan Sumber: Data sekunder diolah, 2019 (Lampiran 5)

Berdasarkan Tabel 11. hasil uji signifikansi simultan (Uji F) didapatkan sebuah nilai signifikansi F sejumlah 0,000. Nilai Signifikansi 0,000<0,05 mengindikasikan bahwa variasi Struktur moddal, Ukuran Perusahaan, dan Profitabilitas secara simultan mempengaruhi secara yang signifikan kepada Nilai Perusahaan sehingga model layak digunakan untuk memprediksi.

Tabel 12.

Hasil Uji t

Coefficients $^{\mathrm{a}}$

\begin{tabular}{|c|c|c|c|c|c|c|}
\hline \multicolumn{7}{|c|}{ Coefficients $^{\mathrm{a}}$} \\
\hline \multirow[b]{2}{*}{ Model } & & \multicolumn{2}{|c|}{$\begin{array}{l}\text { Unstandardized } \\
\text { Coefficients }\end{array}$} & $\begin{array}{c}\text { Standardized } \\
\text { Coefficients }\end{array}$ & \multirow[b]{2}{*}{$\mathbf{t}$} & \multirow[b]{2}{*}{ Sig. } \\
\hline & & B & $\begin{array}{l}\text { Std. } \\
\text { Error }\end{array}$ & Beta & & \\
\hline \multirow[t]{4}{*}{1} & (Constant) & -8.459 & .729 & & -11.600 & .000 \\
\hline & Struktur moddal & .077 & .032 & .142 & 2.384 & .019 \\
\hline & $\begin{array}{l}\text { Ukuran } \\
\text { Perusahaan }\end{array}$ & .300 & .025 & .728 & 12.157 & .000 \\
\hline & Profitabilitas & .139 & .061 & .122 & 2.291 & .024 \\
\hline
\end{tabular}

Sumber: Data sekunder diolah, 2019 (Lampiran 5) 
Pengaruh Struktur moddal kepada Nilai Perusahaan Ho: Struktur moddal tidak mempengaruhi secara yang positif kepada Nilai Perusahaan. H1: Struktur moddal mempengaruhi secara yang positif kepada Nilai Perusahaan. Mengacu pada Tabel 12 hasil uji t Struktur moddal kepada Nilai Perusahaan didapatkan nilai signifikansi sejumlah 0,019 dengan nilai koefisien beta 0,077 bernilai positif. Nilai Signifikansi 0,019 $<0,05$ mengindikasikan bahwa $\mathrm{H}_{1}$ diterima. Hasil ini mempunyai arti Struktur moddal mempengaruhi secara secara positif kepada Nilai Perusahaan. Pengaruh Ukuran Perusahaan kepada Nilai Perusahaan Ho: Ukuran Perusahaan tidak mempengaruhi secara secara positif kepada Nilai Perusahaan H2: Ukuran Perusahaan mempengaruhi secara secara positif kepada Nilai Perusahaan. Mengacu pada Tabel 12 hasil uji t Ukuran Perusahaan kepada Nilai Perusahaan didapatkan nilai signifikansi sejumlah 0,000 dengan nilai koefisien beta 0,300 bernilai positif. Nilai Signifikansi menunjukkan $0,000<0,05$ mengindikasikan bahwa $\mathrm{H}_{2}$ diterima. Hasil ini mempunyai arti bahwa Ukuran Perusahaan mempengaruhi secara secara positif kepada Nilai Perusahaan. Pengaruh Profitabilitas kepada Nilai Perusahaan. Ho: Profitabilitas tidak mempengaruhi secara secara positif kepada Nilai Perusahaan. H3: Profitabilitas mempengaruhi secara secara positif kepada Nilai Perusahaan. Mengacu pada Tabel 12 hasil uji t Profitabilitas kepada Nilai Perusahaan diperoleh nilai signifikansi sejumlah 0,024 dengan nilai koefisien beta 0,139 bernilai positif. Nilai Signifikansi 0,024 $<0,05$ mengindikasikan bahwa $\mathrm{H}_{3}$ diterima. Hasil ini mempunyai arti bahwa Profitabilitas mempengaruhi secara secara positif kepada Nilai Perusahaan.

Mengacu pada hasil uji t Struktur moddal kepada Nilai Perusahaan didapatkan nilai signifikansi sejumlah 0,019 dengan nilai koefisien beta 0,077 bernilai positif. Nilai Signifikansi sejumlah $0,019<0,05$ mengindikasikan bahwa $\mathrm{H}_{1}$ diterima. Hasil ini mempunyai arti Struktur moddal mempengaruhi secara secara positif kepada Nilai Perusahaan. Dengan kata lain semakin meningkat Struktur moddal akan semakin meningkatkan Nilai Perusahaan, sebaliknya jika Struktur moddal akan semakin menurun, maka Nilai Perusahaan juga akan mengikuti penurunan pula. Hasil penelitian tersebut sejalan dengan hipotesis dua $\left(\mathrm{H}_{1}\right)$ yang diajukan dan sesuai seperti penelitian yang dikerjakan oleh (Brigham \& Houston, 2011),(Wiagustini, 2010). (Rizqia et al., 2013), dan (Eka Lestari, 2010) memperoleh hasil Struktur moddal memiliki peran pengaruh secara positif dan signifikan kepada nilai perusahaan. Bahwa adanya pengaruh positif dan signifikan kepada nilai perusahaan, temuan ini didukung oleh trad off theory yang menyatakan bahwa (dengan asumsi titik target Struktur moddal yang dicapai belum mampu terlaksana secara optimal) peningkatan rasio utang kepada stuktur modal sekaligus akan mampu memberi nilai yang meningkatkan nilai perusahaan

Berdasarkan hasil uji $t$ Ukuran Perusahaan kepada Nilai Perusahaan didapatkan nilai signifikansi sejumlah 0,000 dengan nilai koefisien beta 0,300 bernilai positif. Nilai Signifikansi $0,000<0,05$ mengindikasikan jika $\mathrm{H}_{2}$ dapat diterima. Hasil ini mempunyai arti jika Ukuran Perusahaan memberi perngaruh secara positif kepada Nilai Perusahaan. Istiah lainnya yaitu semakin meningkat Ukuran Perusahaan akan semakin meningkatkan Nilai Perusahaan, sebaliknya jika 
Ukuran Perusahaan semakin mengalami penurunan maka Nilai Perusahaan akan ikut semakin menurun. Hasil penelitian tersebut telah sesuai seperti hipotesis dua $\left(\mathrm{H}_{2}\right)$ yang diajukan dan sesuai seperti penelitian yang dikerjakan oleh (Cuong \& Canh, 2012), (Mohamad \& Abdullah, 2012), dan (San \& Teh Boon, 2011)yang mendefinisikan jika terjadi pengaruh secara positif dan juga signifikan antara ukuran dari perusahaan kepada nilai perusahaan, hal ini memiliki arti bahwa meningkatnya ukuran perusahaan akan sekaligus memberi kemudahan perusahaan mendapat dana, yang selanjutnya bisa digunakan oleh pihak manajweial guna tujuan membuat peningkatan nilai perusahaan.

Berdasarkan hasil uji t Profitabilitas kepada Nilai Perusahaan didapatkan nilai signifikansi sejumlah 0,024 dengan nilai koefisien beta 0,139 bernilai positif. Nilai Signifikansi 0,024 $<0,05$ mengindikasikan bahwa $\mathrm{H}_{3}$ diterima. Hasil ini mempunyai arti bahwa Profitabilitas mempengaruhi secara secara positif kepada Nilai Perusahaan. Hal ini juga bisa disebut bahwa semakin meningkat Profitabilitas akan semakin meningkatkan Nilai Perusahaan, sebaliknya jika Profitabilitas performanya menurun Nilai Perusahaan juga mengalami penurunan. Hasil penelitian ini sejalan dengan hipotesis dua $\left(\mathrm{H}_{3}\right)$ yang diajukan dan sesuai dengan penelitian yang dikerjakan oleh (Sahay \& Pillai, 2009), (Wulandari, et al. 2015), dan (Chen \& Chen, 2011), yang memperoleh bukti bahwa kenaikan laba atau profitibilitas yang diperoleh perusahaan dapat meningkatkan nilai perusahaan.

\section{SIMPULAN}

Struktur moddal mempengaruhi secara secara positif kepada Nilai Perusahaan. SImpulan ini diperoleh dari nilai signifikansi sebesar 0,019<0,05 dengan nilai koefisien beta 0,077 bernilai positif. Dengan isttilah lainnya bahwa semakin meningkat Struktur moddal akan semakin meningkatkan Nilai Perusahaan, sebaliknya Struktur moddal akan semakin menurun, Nilai Perusahaan akan ikut mengalami penurunan pula.

Ukuran Perusahaan memiliki pengaruh secara positif kepada Nilai Perusahaan. Hal ini tergambar dari nilai signifikansi sebesar $0,000<0,05$ dengan nilai koefisien beta 0,300 bernilai positif. Dengan kata lain semakin meningkat Ukuran Perusahaan akan semakin meningkatkan Nilai Perusahaan, sebaliknya jika Ukuran Perusahaan semakin mengalami penurunan maka Nilai Perusahaan juga akan semakin menurun.

Profitabilitas mempengaruhi secara secara positif kepada Nilai Perusahaan. nilai signifikansi sebesar $0,024<0,05$ dengan nilai koefisien beta 0,139 bernilai positif. Dengan kata lain semakin meningkat Profitabilitas akan semakin meningkatkan Nilai Perusahaan, sebaliknya jika Profitabilitas semakin menurun maka Nilai Perusahaan akan semakin menurun.

Bagi Mahasiswa, Hasil penelitian ini dapat digunakan sebagai sumber ajar alternatif untuk manambah materi terkait mata perkuliahan terkait. Bagi perusahaan real estete, hasil penelitian ini dapat digunakan untuk bahan informasi dan masukan kepada pihak manajemen guna untuk memperbaiki Nilai Perusahaan agar lebih baik kedepannya. Hal tersebut dapat dilakukan dengan cara 
meningkatkan Struktur moddal, Ukuran Perusahaan, dan Profitabilitas. Dengan demikian Nilai Perusahaan dapat dioptimalkan. Bagi Universitas, Hasil penelitian ini dapat digunakan sebagai rekomendasi sumber ajar atau bahan diskusi pada mata kuliah terkait dalam kegiatan perkuliahan.

Bagi Peneliti berikutnya yang akan melakukan penelitian lebih mendalam terkait dengan pengaruh meningkatkan Struktur moddal, Ukuran Perusahaan, dan Profitabilitas kepada Nilai Perusahaan pada perusahaan real estete yang namanya telah terdata di Bursa Efect Indonesia dapat dilakukan dengan menambah sampel perusahaan serta menambah data berdasarkan tahun guna mendapatkan hasil yang sesuai dengan kenyataan sebenarnya

\section{REFERENSI}

Ahmad, Z., Abdullah, N., \& Roslan, S. (2012). Capital Structure Effecton Firms Performance: Focusing on Consumers and Industrials Sectorson Malaysian Firms. International Review of Business Research Papers, 8(5), 137-155.

Brigham, E., \& Houston, J. (2011). Dasar-dasar Manajemen Keuangan Terjemahan. Jakarta: Salemba empat.

Chen, L.-J., \& Chen, S.-Y. (2011). The influence of profitability on firm valuew ith capital structure as the mediator and firmsize and industry as moderators. Investment Management and Financial Innovations Journal, 8(13).

Cuong, N., \& Canh, N. T. (2012). The Factors Affecting Capital Structure for Each Group of Enterprises in Each Debt Ratio Threshold: Evidence from Vietnam's Seafood Processing Enterprises. International Research Journal of Finance and Economics, 8(9).

Eka Lestari, P. (2010). Pengaruh Struktur moddal dan Kepemilikan Manajerial Serta Ukuran Perusahaan kepada Nilai Perusahaan pada Perusahaan Manufaktur di Bursa Efek Indonesia. Universitas Udayana.

Febri, D., Rahayu, S., \& Wiralestari. (2019). Competence, And Control Systems Government Interns To The. Thesis, 38-52.

Hafzan, F. (2017). Pengaruh Kualitas Laporan Keuangan, Penyajian Laporan Keuangan Dan Aksesibilitas Laporan Keuangan Terhadap Akuntabilitas Pengelolaan Keuangan Daerah. 4(1).

Hilmi, A. (2010). Pengaruh Kejelasan Anggaran, Pengendalian Akuntansi, dan Sistem Pelaporan Terhadap Kinerja Instansi Pemerintahan pada Kabupaten dan Kota di Daerah Istimewa Yogyakarta. Universitas Gajah Mada.

Huang, H., Shih, H., Huang, H., \& Liu, C. op. (2006). Can knowledge management creates firm value? Empirical evidence from United States and Taiwan. The Business Review, Cambridge, 5(1), 178-183.

Modigliani, F., \& Miller, M. (2008). The costof capital, corporation finance and 
the American Economic Review. Research Journal of Financeand Accounting, 4(2), 261-297.

Mohamad, N. E. A. B., \& Abdullah, F. N. (2012). Reviewing Relationship between Capital Structure and Firm's Performance in Malaysia. International Journal of Advances in Management and Economics, 1(4), 151-156.

Mohammed, M. Bin, \& Sawandi, N. B. (2003). (CSR) Activities In Mobile Telecommunication Industry: Case Study of Malaysia. Faculty of Accountancy University Utara Malaysia, 1(3).

Pramana, I. G. N. A. D., \& Mustanda, I. K. (2016). PENGARUH PROFITABILITAS DAN SIZE TERHADAP NILAI PERUSAHAAN DENGAN CSR SEBAGAI VARIABEL PEMODERASI Fakultas Ekonomi dan Bisnis Universitas Udayana ( Unud ), Bali , Indonesia PENDAHULUAN Perusahaan sebagai salah satu entitas ekonomi di suatu negara sudah se. EJurnal Manajemen Unud, 5(1), 561-594.

Rizqia, D. A., Aisjah, S., \& Sumiati. (2013). Effect of Managerial Ownership, Financial Leverage, Profitability, Firm Size, and Investment Opportunity on Dividend Policy and Firm Value. Research Journal of Financeand Accounting, 4(11).

Sahay, \& Pillai. (2009). Differential impact of advertising and distribution expenditure on Tobin's Q: A perspectivefrom listedfirms in India. Journal of Indian Business Research, 1(2).

San, O. T., \& Teh Boon, H. (2011). Capital Structure and Corporate Performance o Malaysian Construction Sector. International Journal of Humanities and Social Science, 1(2).

Sari, E., Azlina, N., \& Julita. (2017). Pengaruh Sistem Pengendalian Intern, Penyajian Laporan Keuangan, Aksesibilitas Laporan Keuangan Dan Gaya Kepemimpinan Terhadap Transparansi Dan Akuntabilitas Pengelolaan Keuangan Daerah Di Kabupaten Indragiri Hulu. Jurnal Online Mahasiswa Fakultas Ekonomi Universitas Riau, 4(1), 571-585.

Sunarto, \& Budi. (2009). Pengaruh Leverage, Ukuran dan Pertumbuhan Perusahaan terhadap Profitabilitas. Jurnal Telaah Manajemen, 6(1).

Wiagustini, N. luh P. (2010). Dasar-Dasar Manajemen Keuangan. Denpasar: Udayana University Press.

Wijaya, B. I., \& Sedana, I. B. S. (2015). Pengaruh Profitabilitas Terhadap Nilai Perusahaan (Kebijakan Dividen Dan Kesempatan Investasi Sebagai Variabel Mediasi). E-Jurnal Manajemen Unud, 4(12), 4477-4500.

Wulandari, Y., Juwita, R., \& Trisnadi Wijaya, T. (2015). Pengaruh Struktur 
E-Jurnal Manajemen, Vol. 9, No. 6, 2020 : 2394-2413

moddal, return on equity (roe), dan kebijakan dividen kepada nilai perusahaan. Journal of Indian Business Research, 1(14).

Zeyn, E. (2012). Pengaruh Penerapan Good Governance Dan Standar Akuntansi Pemerintahan Terhadap Kualitas Informasi Keuangan. Jurnal Ilmiah, 1(1), $1-14$. 